\title{
Citizen-centred or state-centred? The representational design of international parliamentary institutions
}

\author{
Thomas Winzen \& Jofre Rocabert
}

\begin{abstract}
As a result of the spread of international parliamentary institutions (IPIs), international organizations face crucial questions of representational design. We introduce a distinction between citizen-centred or statecentred IPIs in international organizations (IO). Drawing on new data, we show that, even though parliaments might seem likely to foster citizen representation in the international realm, they in fact often follow state-centred representational designs. We further find that citizen-centred IPIs are a near exclusive phenomenon of a few, democratic regional integration projects. Given the prevalence of state-centred representational designs, we conclude that IPIs' potential to represent different cross-border communities, concerns, and conflict lines than intergovernmental IO bodies remains institutionally limited. IPIs are thus unlikely to challenge these bodies in similar ways as often observed in the relationship between the European Parliament and the European Union's Council of Ministers.
\end{abstract}




\section{Introduction}

When governments create international organizations (IOs), they face questions of representational design. Choices such as how to select the decision-makers in international bodies inevitably trigger tense conflicts. Unsurprisingly, therefore, crucial decisions in the creation of intergovernmental bodies have been widely discussed—such as the choice between majority voting and keeping the national veto (e.g. Rapkin 2016; Blake and Payton 2015). However, in recent decades, IOs have become more complex (Hooghe et al. 2017). They have increasingly created representative bodies for civil society and other stakeholders as well as for parliamentarians (Tallberg et al. 2014; Lenz et al. 2015; Šabič 2008; Kraft-Kasack 2008; Dri 2010; Habegger 2010; Jancic 2019; Cofelice 2019; Rocabert et al. 2019). Yet, paradoxically, we still know little about the representational design of these international bodies even though they most explicitly serve the purpose of representation.

We explore the representational design of international parliamentary institutions (IPIs). IPIs are transnational arenas of delegates of national parliaments or elected representatives. As formal organisations, IPIs differ from a wider universe of parliamentary diplomacy, friendship groups, networks and conferences (Cutler 2001; Stavridis and Jancic 2017; Cofelice 2019). IPIs have been given many labels, such as international parliamentary organ or assembly (Kraft-Kasack 2008; Jönsson and Johnsson 2018; Cofelice 2019), and generic names such as representative assembly or body. Yet, despite subtle differences, IPI is the most common and general term and will be used here alongside more generic terms (e.g., Klebes 1990; Šabič 2008; Kissling 2014; Jancic 2019; Rocabert et al. 2019). ${ }^{1}$ Although their authority often remains weak, IPIs have become a common feature of IOs (Šabič 2008; Kraft-Kasack 2008; Dri 2010; Habegger 2010; Kissling 2014; Jancic 2019; Cofelice 2019; Rocabert et al. 2019; Malang 2020; Lipps 2020).

\footnotetext{
${ }^{1}$ Some scholars distinguish organs, which are bodies of international organizations, and assemblies, which are not. We do not object to this distinction where a risk of confusion requires new labels, but prefer to use IPI as the more general and better-known term. Moreover, by referring to international parliamentary institution we highlight that these bodies share essential attributes with a well-known class, parliaments, but are not functionally equivalent - whether IPIs can or should grow similar to national parliaments in authority or other respects beyond the fundamental organizational traits that define them as parliamentary institutions is open for debate and analysis (Schimmelfennig et al. 2020).
} 
IPIs are often cursorily described as mechanisms of citizen representation in IOs and thus as different from intergovernmental IO bodies that represent national governments (Falk and Strauss 2001; Cofelice 2019; Kraft-Kasack 2008; Šabič 2008). We do not object to this perspective but note that it leaves open questions. In particular, which actors and concerns IPIs can be expected to represent depends partly on representational design. For example, recent studies highlight design alternatives such as whether IPIs should be directly elected, how seats should be allocated, or whether they should create national or transnational factions (Jancic 2019: 229; Habegger 2010; Cofelice 2019:188-189; Dri 2010: 65-70). While institutional choices such as these do not determine behaviour in IPIs, scholars believe that they influence whether IPIs might represent different actors, concerns, and conflict lines than intergovernmental IO bodies, and thus whether they are likely to contribute to or challenge the legitimacy of such bodies and their strong role in many IOs (Habegger 2010; Cofelice 2019: 188-189; Kraft-Kasack 2008; Jancic 2019: 229).

This study contributes to the development of this literature, first, by conceptualizing ideal-typical representational design alternatives for IPIs. Specifically, we argue that IPIs could adopt a citizen-centred representational design but also a more state-centred alternative. They could implement direct elections, distribute seats according to votes, and organize the parliament into ideological factions or, instead, favour national delegations, equal seats per state, and national political groups. Depending on these choices, IPIs might give rise to a bicameral structure in IOs, akin to the situation in the European Union, or stay closer to the idea that IO bodies represent states and state-based communities. While representational design alternatives should not be expected to determine the behaviour of IPIs or their members, they might render it more or less probable that IPIs would behave similarly to, for example, the European Parliament - that is, independent of and regularly in conflict with national governments (Hix 2002; Rittberger 2005).

We furthermore contribute new data and evidence by describing the distribution and correlates of the representational design of IPIs on a global scale. Covering all 38 IPIs that exist within IOs from 1945-2019, we show that state-centred representational design has remained the norm in IPIs. Only two existing parliamentary bodies are strongly citizen-centred: the European Parliament and the parliament of MERCOSUR. While half of all IPIs display at least one citizen-centred trait, the overall picture is that they 
adopt state-centred designs predominantly. We then show that citizen-centred IPIs - and direct elections and cross-border factions in particular - are a near exclusive phenomenon of a few democratic regional integration projects including the European Union and major Latin American IOs. In contrast, in parts of the world in which IOs as well as domestic politics remain state-centred, so do IPIs.

In the following, we first embed our study in the literature on IPIs. Second, we elaborate the distinction between citizen-centred and state-centred representational design and, third, map the empirical distribution of these designs over time and IOs. Fourth, we highlight arguments often made about the contexts in which citizen-centred IPIs are likely to be found and, fifth, present corresponding empirical evidence of the correlates of citizen-centred IPIs.

As discussed further in the conclusion, our results do not mean that IPIs fail to expand the range of representation mechanisms of existing IOs. Yet, their potential to represent different cross-border communities, concerns, and conflict lines than intergovernmental IO bodies remains institutionally limited not only due to their commonly weak authority but also given the prevalence of state-centred representational designs. We also highlight avenues of further research with a focus on examining the behavioural effects of representational design further.

\section{Representational design and international parliamentary institutions}

Representational design focuses on rules that shape descriptive and substantive representation: the classes of actors and concerns that are made present by the participants in international decision-making (Rapkin et al. 2016). Thus conceived, representational design is hardly a new problem. Any IO reform brings controversy over voting rights in key organizational bodies (Blake and Payton 2015). Many IOs have faced conflicts over the participation and power of weaker and stronger, richer and poorer, nearer and farther, or bigger and smaller states (Rapkin et al. 2016).

Yet, the representational design of IOs is not limited to intergovernmental bodies. IOs have grown more complex in recent decades (Hooghe et al. 2017), as governments have established bodies for the representation of stakeholders (e.g., civil society organizations or private companies) and parliamentarians 
(Tallberg et al. 2014; Lenz et al. 2015; Šabič 2008; Kraft-Kasack 2008; Dri 2010; Habegger 2010; Jancic 2019; Cofelice 2019). As explained further below, almost 40 IPIs now exist within IOs (Rocabert et al. 2019). As organisations of representatives delegated by their national parliaments or elected directly, IPIs differ fundamentally from diplomatic assemblies or independent agencies. IPIs do not formally consist of states, as the UN General Assembly, nor of national governments or the diplomats representing them in the UN and intergovernmental organs of IOs around the world. As representative bodies, IPIs also differ from hierarchical international bureaucracies and their unelected officials (Falk and Strauss 2001; Rocabert et al. 2019) as well as from the stakeholder bodies now found in many IOs and other international contexts, which are composed of selected or self-selected organizations and policy practitioners employed by these organizations.

The creation of these bodies is a representational design choice in itself and part of wider efforts to "open up" executive-dominated IOs (Tallberg et al. 2014). While stakeholder bodies could be said to foster function-centred representation, IPIs have been seen as potential sources of citizen representation beyond the state (Falk and Strauss 2001; Kissling 2014; Lenz 2013; Rocabert et al. 2019; Kraft-Kasack 2008; Šabič 2008; Habegger 2010). Some regard them as sources of legitimacy 'because as parliamentarians, their members are the only actors that are directly accountable to their voters' (Šabič 2008: 267). Even critics that highlight the weaknesses of existing IPIs consider them a potential source of citizen representation (Vaubel 2006: 130-131; see also Habegger 2010; Kraft-Kasack 2008). Cofelice (2019:188-189) notes that although most IPIs have only a consultative role in IO decision-making, they have the ability to promote legitimating civic dialogue. Consequently, one would expect the representational design of IPIs to have received significant attention.

Yet, surprisingly little attention has been devoted to the representational design of IPIs. A substantial part of the existing literature on these bodies focuses on explaining their existence rather than their design. Early studies already tried to account for IPIs as institutional innovations within specific international domains (Hall 1942; Lochen 1958; Hovey 1966). In one of the first comparative studies on IPIs, Lochen (1958) states: 'The first question which may be raised is why a parliamentary association with European co- 
operation has come into existence at all.' When a research agenda on IPIs began to emerge, authors explored new questions such as the role of IPIs in regional politics (Sabic 2008; Stravidis and Pace 2011) or the relationships between the EP and other IPIs (Grabendorff 1992; Cofelice and Kingah 2012). However, most contributions still focused on the emergence of IPIs, from a comparative perspective (Kebles 1990; Cutler 2013; Lenz 2013; Cofelice 2018; Rocabert et al. 2019), or within a specific case or region (Rittberger 2005; Dri 2010; Navarro 2010; Mumford 2018; Jancic 2019; Verdoes 2020).

To some extent, scholars have also examined the decision-making authority of IPIs (Malamud and de Sousa 2007; Dri 2010: 67-70; Cofelice 2018:145-184). Yet, the general conclusion of this literature is that, despite their remarkable spread, almost all IPIs remain weak in terms of authority, and the European Parliament an exception that has gained legislative competences on the basis of mechanisms so far not observed elsewhere (Rittberger 2005; Héritier 2007; Roederer-Rynning and Schimmelfennig 2012). In line with this view, we take the weak authority of IPI as indication that, at present, their relevance might rather lie in their ability to represent in ways that differ from the representation that governmental organs in IOs already provide.

Starting from this premise, several studies have examined the representational design of IPIs more directly. Dri (2010: 65-70), for example, explores the organization of Parlasur and stresses, amongst other features, the allocation of seats, electoral mechanism, and whether members divide into ideological or country groupings. Similarly, Jancic (2019: 224) does not only study the authority of four African IPIs, but also their electoral mechanisms and, to some extent, whether they foster 'cross-border political alignment and the formulation of common transnational political platforms.' In addition, Giesen (2017) and Cofelice (2019:5171) present more extensive, systematic data on the design of IPIs. As Dri and Jancic, both authors allude to a distinction between 'country' and 'trans-national' representation and relate this to mechanisms for elections and the distribution of seats between countries. While we build on the valuable insights of these studies (see also Kraft-Kasack 2008), we also note that they all have a more heuristic interest in the organization of IPIs. Consequently, despite an emerging focus on core factors - notably elections, seat allocation, and some element of non-country-based parliamentary groups - not all of these factors are examined consistently across studies. Moreover, design characteristics that are not linked to representation 
are commonly considered in addition. In this respect, it is a logical next step for the literature to discuss more explicitly which IPI characteristics are essential parts of representational design, and to compare these characteristics more systematically.

Finally, an emerging literature on IPIs and the legitimacy of IOs is relevant here. Legitimacy can be understood either as compatibility of an IO's design or practices with normatively defined standards such as accountability or as 'beliefs within a given constituency or other relevant audience that a political institution's exercise of authority is appropriate' (Tallberg and Zürn 2019: 585). Critics object that, without significant authority, IPIs are irrelevant for IOs and their legitimacy - irrespective of their representational design. To some extent, this is a valid concern. For example, Habegger (2010) argues that the ability of IPIs to foster accountability of IO decision-makers, especially governments, depends on their competences in the legislative process. Kraft-Kasack (2008: 537-538) considers IPI influence on decisions and appointments in IOs an important - and typically unfulfilled - criterion for democratic legitimacy. And Jancic (2019: 226) observers a 'striking mismatch between the normative framework and the practical functioning of regional parliaments [in Africa]' in part due to weak decision-making powers. At first, the ability of IPIs to affect the legitimacy of IOs thus seems limited.

However, the conclusions of this literature are more nuanced. Even without authority, IPIs still contribute to the representation of different groups of actors and concerns. IPI members can also actively advocate continuity and change in an IO, and thus contribute to or erode the legitimacy of the organizational status quo in the eyes of audiences such as citizens or political elites. For example, Habegger (2010) argues that IPIs might represent different actors, concerns, and conflict lines than governmental organs (see also Cofelice 2019:188-189). Jancic (2019: 229) suggests that IPIs could lend attention to regional problems, alliances that cross-cut national borders and, more generally, the existence of a cross-border or transnational political community. If IPIs do so, they contribute to weakening the legitimacy of organizations in which inter-state bargaining and intergovernmental organs dominate, but strengthen the legitimacy of organizations that aim to achieve a transnational political community (see also Kraft-Kasack 2008). 
Importantly, however, IPIs do not necessarily have these implications. Rather, we share Kraft-Kasack's (2008) view that design influences whether actors in IPIs are likely to challenge or support the legitimacy of different IOs. Some design choices make it more likely that IPIs offer different representation than intergovernmental IO bodies. For example, it is intuitively plausible that the literature, despite examining diverse IPI characteristics, often shares a focus on elections, seat distributions, and cross-border parliamentary groups. These design elements, as we explain below, can plausibly be expected to shape whether IPIs align with or challenge intergovernmental bodies. For example, the European Parliament's directly elected members and transnational groups have long been advocates of a federalist trajectory for the European Union and opponents of an intergovernmental model (Rittberger 2005; Scully 2005). In contrast, critics of a federal European Union have suggested to turn the European Parliament into a Senate of delegates of national parliaments instead - in part motivated by the belief that such an institution would be less likely to promote federalism and more supportive of the Council of Ministers (e.g., Schyff and Leenknegt 2007). The broader implication is that, to fully appreciate which change in IOs, if any, IPIs might encourage, we also need to know more about their representational design in addition to their existence and authority.

In sum, there is growing interest in the representational design of IPIs, not least because it is believed that alternative design choices could foster support for or challenges to the legitimacy of the status quo of different IOs. Clearly, however, significant research is still required to fully elaborate these claims, both in terms of conceptualizing and mapping representational design alternatives systematically and for more cases than has been done so far, and in linking them to political behaviour. The first of these tasks, which we pursue here, can be considered a prerequisite for further progress in the literatures outlined so far.

\section{Citizen-centred and state-centred international parliamentary institutions}

What are the main alternatives for the representational design of IPIs? We build on the interest in the literature, as discussed above, in more country-oriented or more transnational designs, which we label statecentred and citizen-centred, respectively. Our discussion excludes a function-centred alternative because 
function-centred representation is the domain of stakeholder bodies (e.g., Tallberg et al. 2014). Indeed, empirically, none of the IPIs in our analysis has adopted what could plausibly be considered a functioncentred representational design. We further stay in line with the literature by treating elections, seat allocation, and cross-border groups as core attributes of our ideal-typical design alternatives. Yet, whereas existing research develops these distinctions inductively based on mapping diverse organizational characteristics of IPIs, we highlight that they can be derived from a wider literature on parliamentary design. We believe this to be important since this body of work has long examined implications of alternative design choices and can thus inform the study of IPIs.

The design of parliaments is a core concern of scholars of representation in domestic politics. From the outset, it needs to be stressed that parliamentary design offers a seemingly infinite variety of choices-from basic questions about parliamentary architecture, sources and distribution of resources, to the fine details of committee assignments, information rights, and investigative procedures (e.g., Döring 1995; Fish and Kroenig 2009; Martin et al. 2014). Moreover, all of these choices could conceivably influence whose concerns and interests find representation, as is evident in extensive debates about the distributional implications of different committee rules in the US Congress, European national parliaments, and the European Parliament (Krehbiel 1991; Strom 1998; Bowler and Farrell 1995).

However, rather than covering all choices, we take inspiration from Powell's (2000: 20-46) analysis of the representational principles underlying national parliaments and focus on three crucial issues: the rules for the selection of parliamentarians, the apportionment of seats between different groups of IPI members, and the factional organization of the IPI. We limit our focus for two reasons. First, unlike many other choices, the ones we study have direct and clear implications for the actors and concerns that obtain parliamentary representation. As Powell, we suggest that such fundamental choices are indicative of a wider range of detailed choices. Second, focussing on major design choices is also a practical necessity. A lot of the detailed 
information that we might have for widely known bodies cannot be obtained for a global sample of IPIs over time. ${ }^{2}$

Table 1. Representational designs for international parliamentary institutions

\begin{tabular}{lll}
\hline & Representational design \\
Institutional choice & Citizen-centred & State-centred \\
\cline { 2 - 3 } $\begin{array}{ll}\text { Selection of members } \\
\text { Apportionment of seats } \\
\text { Legislative factions }\end{array}$ & $\begin{array}{l}\text { Direct elections } \\
\text { Proportional to population } \\
\text { Ideological }\end{array}$ & $\begin{array}{l}\text { Parliamentary delegations } \\
\text { Equal seats per country } \\
\text { Territorial }\end{array}$ \\
\hline
\end{tabular}

Different representational design choices create different ideal-typical parliaments (see Table 1). If IPIs were similar to lower houses of national parliaments, which represent a country's citizens, they would be elected, allocate seats proportional to population, and divide into ideological factions. We call this design citizen-centred. In contrast, many upper houses represent jurisdictions or communities, especially in federal and multinational political systems akin to the environments in which IOs operate (e.g., Tsebelis and Rasch 1995). Since, in the international realm, these jurisdictions are states, we call this design state-centred. Statecentred IPIs feature delegated representatives, seat allocation by territorial unit, and factions that follow territorial boundaries. Both citizen-centred and state-centred IPIs are composed of parliamentarians and in this sense different from intergovernmental organs, yet their representational reference points differ. Statecentred IPIs build on the assumption that states and state-based communities require representation at the international level whereas the citizen-centred institutions focus on the representation of citizens directly irrespective of the borders between the member states of an IO (see Cheneval 2011 for a broader discussion of these alternative assumptions about representation at the international level). ${ }^{3}$

\footnotetext{
${ }^{2}$ A good example of this is budget data. We have been able to obtain information on the size and sources of IPI budgets for a dozen bodies, mostly in Europe, for very recent years. However, such information is rarely available for IPIs from less wealthy or stable regions and IOs, especially for longer periods of time.

3 Alternative labels such as direct v. indirect, democratic v. demoi-cratic, or individual v. clustered, group- or jurisdiction-based would be conceivable. However, these labels are less intuitive and specific as they do not directly refer to the different assumptions underlying alternative representational designs.
} 
IPIs do not necessarily follow either ideal-typical design entirely. Rather, the three dimensions of representational design divide IPIs into more citizen- or more state-centred types. Direct elections create a new delegation chain that by-passes governments and limits their control over the actors and concerns represented in international decisions (Benz 2003; Rittberger 2005). If, instead, IPIs are composed of delegates from national parliaments, controlled by the domestic majority, they will preserve the domestic balance of power or even consist of government loyalists entirely. Among the IPIs in our data that consist of delegated members, some explicitly recommend that delegations respect the domestic distribution of power. For example, the statutes of the Baltic Assembly state that the members must be elected by national parliaments "in accordance with the approved rules of procedure and the principle of proportional political representation" (Baltic Assembly 2017:1). The IPI of the Community of Portuguese Language Countries is more explicit and stipulates that the national delegations should be constituted "in accordance to the electoral results" (Community of Portuguese Language Countries 2009:1).

Policy-makers fully understand the importance of choosing an electoral mechanism. It took the European Parliament until 1979 to convince governments to hold the direct elections envisaged in the 1951 Treaty on the European Coal and Steel Community. Elsewhere governments discovered the risks involved in direct elections after the fact. Venezuela ended direct elections to the Latin American Parliament after the domestic opposition had come to dominate the parliamentary delegation (El Nacional 2015). Colombia also abolished direct election to the Andean Parliament after a governmental controversy in 2011. Elections can also cause problems between large and small countries. In the case of the Eurasian Economic Union, Russia proposed direct elections to the Eurasian Parliament, while Kazakhstan and Belarus objected, fearing Russian ambitions (Schimmelfennig et al. 2020:134-135).

Representational design also involves decisions on the allocation of IPI seats. Many allocation principles are conceivable, but two alternatives exist empirically: to distribute seats proportional to population or equally to each country. ${ }^{4}$ Proportional representation is the citizen-centred choice since it gives large groups

\footnotetext{
${ }^{4}$ Proportional representation can have a regressive element. This means that large jurisdictions obtain somewhat fewer and small ones somewhat more seats than proportionality would require. Even under regressive proportionality, the
} 
of citizens many representatives and makes attention to their concerns likely. Minority interests, such as of the citizens of small states, are de-emphasized by design unlike in state-centred alternatives that give equal parliamentarians to each country. Proportional seat allocation need not go against every government's interests. Governments of large countries could benefit if other countries are small. Proportionality also loses relevance if jurisdictions are equally large. However, as most IOs involve small states and require unanimous institutional decisions, citizen-centred seat allocation is, in principle, likely to encounter resistance. A case in point is the discussion that emerged in 2003 during the design of the parliament of Mercosur, a South American IO. The two largest states, Brazil and Argentina, championed the idea that the IPI should have proportional representation. This did not fare well with officials from Paraguay and Uruguay, which have populations dozens of times smaller than their neighbours. The disagreement was only resolved when Uruguay elected the integrationist President Vazquez (Schimmelfennig et al. 2020: 184).

Finally, IPIs differ in the organisation of factions: groups that facilitate collective action among representatives. Factions rely on working groups and party leaders to establish a party line (Kam 2014). As "competing principals", they demand loyalty besides other principals (Carey 2007). If principals disagree, politicians experience cross-pressure as, for instance, members of ideological groups that also have territorial constituencies (Carey 2007; Carey and Shugart 1995). Congruence between legislative bodies—such as in a bicameral parliament—helps avoid cross-pressures (e.g., Tsebelis and Rasch 1995). In the case of IPIs, the main question is whether parliamentarians will sit in ideological or national groups. The contemporary European Parliament is an example of the former model and, consequently, members regularly face tensions between the European party groups and national governments (Hix 2002). Even before direct elections, the European political groups contributed importantly to the evolution of a transnational outlook among its members that often led to conflicts with national governments (Guerrieri 2008). More generally, ideological factions that cross-cut territorial boundaries are at odds with the representation of territorial state interests (Hix et al. 2007: 54-71).

difference to equal seats per country is typically clearly evident, however, as in the case of the European Parliament. 


\section{Mapping the representational design of international parliamentary institutions}

How are citizen- or state-centred and state-centred IPIs distributed empirically? We created a dataset on the representational design of 38 IPIs within IOs from 1945 to 2019 (for a full list and further discussion of the selection, see the appendix). The number of IPIs in existence depends on how we distinguish these bodies from looser parliamentary networks. Not making this distinction overestimates the number of IPIs significantly. For example, a widely noted list by Kissling (2014) incorporates over 100 cases while other studies cover varying numbers of fewer cases (e.g., Cutler 2001; Cofelice 2019). We focus on a smaller number because we are interested in bodies that are, as parliamentary bodies at the national level, formal organizations. IPIs are organizations in the sense of having an establishing treaty laying out their structure and functioning, a bureau or secretariat, and one or, as in the example of the European or the Benelux Parliament, very few permanent locations. IPIs also need to meet our criteria of being arenas with members elected directly or delegated by national parliaments. Our list focuses on IPIs that, as national parliaments, are affiliated with a wider political structure - IOs in our case. ${ }^{5}$ For these cases, the analogy to national parliaments on which our conceptual discussion draws is most plausible although it might also apply to IPIs that are not affiliated with IOs. It would, however, be a category mistake to assume that design choices derived from national parliaments can or should be applied to looser gatherings such as parliamentary networks.

Our data capture whether parliamentary bodies are directly elected, allocate seats by population or equally by country, and organize into state or ideological factions. While often straight-forward, there are grey areas in this classification. For example, in the case of direct elections, some IPIs have declared their intention to hold elections but have not done so. This is the case in four African IPIs, the Latin American Parliament, and the parliamentary body of the Union between Russia and Belarus.

\footnotetext{
5 As noted earlier, for this reason some scholars might prefer to refer to the IPIs in our study as international parliamentary organs to underline their affiliation to an IO, but the more widely known term, IPI, while being more general, remains accurate nonetheless.
} 
Figure 1 charts the evolution of citizen-centred representational designs over time. Today, around $45 \%$ of existing IPIs within IOs have the intention to hold direct elections, or to allocate seats in proportion to member state populations, or to organize into ideological factions (17 out of 38 existing in $2019^{6}$ ). However, this percentage drops to $34 \%$ if we discount IPIs which intend to but have not actually held elections. It falls further to $15 \%$ if we only count IPIs which have two or more citizen-centred characteristics. Only six IPIs meet this standard: the European Parliament and the MERCOSUR Parliament (both fully citizen-centred) as well as the Council of Europe Parliamentary Assembly, the Nordic Council, the Benelux InterParliamentary Council, and the Central American Parliament. Overall, citizen-centred designs remain relatively rare. The small group of (partly) citizen-centred IPIs emerged in two decades, the 1950s and the 1990s. In fact, during the 1950s most of the IPIs were created with proportional representation. It was only during the late 1980s and 1990s, at the height of IPI growth, when the Mercosur and Central American parliaments moved towards citizen-centred designs.

\section{Figure 1. Citizen-centred designs in international parliamentary institutions}
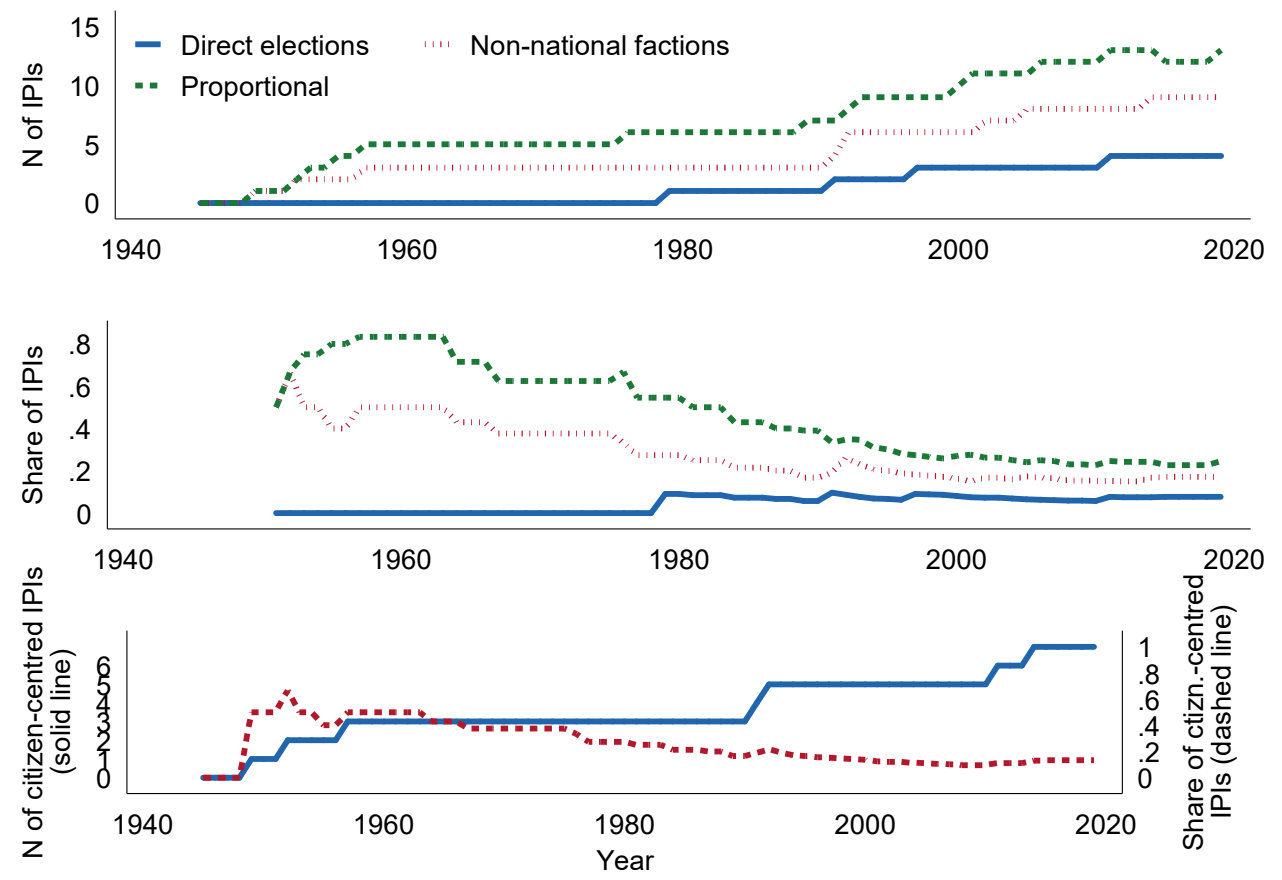

\footnotetext{
${ }^{6}$ The IPI of the Eurasian Economic Community was dissolved in 2014, bringing down the number of existing IPIs.
} 
Table 2 provides an overview of the cases. Direct elections are the least common citizen-centred design, with only four directly elected IPIs, most partially. IPIs with the goal of holding direct elections began to emerge in the late 1980s-only the European Parliament set itself this goal already in the 1950s. The spread of direct elections stalled in the mid-1990s. Besides the EP, the three major Latin American integration schemes feature elected international representatives, although they remain partially elected.

In all cases, including the European Parliament, elections were not implemented at once or in all countries. In general, governments consider elections costly and have delayed agreed starting dates on multiple occasions. For instance, the Central American presidents agreed to direct elections for their regional IPI in 1986, while most countries did not implement them until at least a decade later. And still, during the last election to this chamber, Panama questioned the vote arguing that the organization would be logistically difficult (Bustamante 2015). The most developed IPI of Latin America, the parliamentary body of Mercosur, had a plan to introduce direct elections in phases until the first simultaneous elections in 2015. However, the deadline was first postponed and in April 2019 governments decided to cancel the plans for direct elections altogether. This, however, has been challenged by the IPI itself and by Argentinian parliamentarians (Rivas Molina 2019; Blanco 2019; Parlamento del Mercosur 2019). Preferring to err on the side of the rarer citizen-centred designs, we consider a case to have direct elections even if only one of the member states holds them.

Turning to the two remaining dimensions of representational design, proportional seat allocation is more common than ideological groupings. Moreover, while almost all of the early IPIs opted for ideological factions and proportional seat apportionment, these designs have since not been conventional in newlyemerging IPIs. In particular, the spread of IPIs in African regional organizations has contributed to this relative decline (Jancic 2019). Nowadays, 30 per cent of the parliamentary bodies of IOs have ideological groups or allocate seats in proportion to population.

Finally, examining the few IPIs that combine two citizen-centred traits suggest some affinity between ideological factions and the proportional allocation of seats. Five out of the six cases with two citizen- 
centred designs (without counting the intent to hold elections) feature this combination. Possibly, whereas distributing equal seats per state encourages politicians to think about their role in terms of state representation, proportional allocation creates incentives to form transnational alliances—for example, for politicians from small countries that would otherwise have little weight.

Overall, Table 2 suggests that the world of IPIs may be divided into Europe-Latin America and Africa-Asia clusters. Europe (including the Eurasian region) and Latin America comprise all IPIs with citizen-centred designs. In contrast, the reason for the stagnation of citizen-centred IPIs is that, since the 1990s, most of these assemblies have emerged in African regional organizations. While these organizations have often been said to have imported European institutional templates (Börzel and Risse 2012; Lenz and Burilkov 2017 Navarro 2010; Cofelice and Stavridis 2014), they have not followed the representational design of the European Parliament. Nearly all IPIs in Africa and Asia feature state-centred designs. While several African IPIs have committed to direct elections formally, the last one being the Pan-African Parliament in 2014, they remain far from this goal in practice (Jancic 2019).

This overview suggests that the probability that IPIs promote cross-border political communities (Jancic 2019: 229) or represent concerns and conflict lines that differ from those represented in intergovernmental organs of IOs (Habegger 2010; Cofelice 2019:188-189) is presently low. Of course, as we noted earlier, representational design does not determine the behaviour of IPIs and their members. However, design choices such as direct elections or ideological factions create favourable structural conditions for the above patterns of behaviour. In contrast, the design of most contemporary IPIs is aligned with an intergovernmental model of international cooperation in which IOs represent states and state-based communities of citizens. 
Table 2. International Parliamentary Institutions affiliated with International Organizations and with at least one citizen-centred characteristic in 2019

\begin{tabular}{|c|c|c|c|c|c|c|}
\hline International parliamentary institution & Founded & Region & Intended & Seat & ctio & ection \\
\hline European Parliament & 1952 & Europe & 0 & 1 & 1 & 1 \\
\hline MERCOSUR Parliament & 1994 & Americas & 0 & 1 & 1 & 1 \\
\hline $\begin{array}{l}\text { Council of Europe Parliamentary } \\
\text { Assembly }\end{array}$ & 1949 & $\begin{array}{c}\text { Cross-regional } \\
\text { (mainly European) }\end{array}$ & 0 & 1 & 1 & 0 \\
\hline Nordic Council & 1953 & Europe & 0 & 1 & 1 & 0 \\
\hline Benelux Inter-Parliamentary Council & 1957 & Europe & 0 & 1 & 1 & 0 \\
\hline Central American Parliament & 1991 & Americas & 0 & 0 & 1 & 1 \\
\hline Andean Parliament & 1979 & Americas & 0 & 0 & 0 & 1 \\
\hline NATO Parliamentary Assembly & 1955 & $\begin{array}{l}\text { Cross-regional } \\
\text { (Western) }\end{array}$ & 0 & 1 & 0 & 0 \\
\hline Central European Initiative Parliament & 1989 & Europe & 0 & 1 & 0 & 0 \\
\hline OSCE Parliamentary Assembly & 1991 & Europe & 0 & 1 & 0 & 0 \\
\hline Baltic Assembly & 1992 & Europe & 0 & 0 & 1 & 0 \\
\hline ECOWAS Community Parliament & 1993 & Africa & 1 & 1 & 0 & 0 \\
\hline Russia-Belarus Union State Parliament & 2000 & $\begin{array}{l}\text { Eastern Europe } \\
\text { Central Asia }\end{array}$ & 1 & 1 & 0 & 0 \\
\hline Pan-African Parliament & 2001 & Africa & 1 & 0 & 0 & 0 \\
\hline $\begin{array}{l}\text { Legislative Assembly of the } \\
\text { East African Community }\end{array}$ & 2001 & Africa & 1 & 0 & 0 & 0 \\
\hline $\begin{array}{l}\text { Economic Community of Central } \\
\text { African States Community Parliament }\end{array}$ & 2010 & Africa & 1 & 0 & 0 & 0 \\
\hline
\end{tabular}

Note: See the appendix for a discussion on the sampling and particular cases.

\section{The regional and organizational contexts of international parliamentary institutions}

Even though fully or even partly citizen-centred IPIs have remained rare, one might ask whether they emerge in IOs and parts of the world in which they could be particularly relevant. We would consider this to be the case if citizen-centred IPIs were commonly found in contexts in which IOs and even domestic politics could otherwise be considered predominantly state-centred. In these contexts, citizen-centred IPIs, even if lacking authority, could illustrate an alternative to the prevailing model of representational design. The potential of 
citizen-centred design to foster representation of actors, concerns, and cross-border alignments other than intergovernmental organs of IO would be most relevant in contexts in which the potential for this pattern of representation is otherwise especially low. Simply put, IPIs might be islands of citizen representation.

The debate about whether this is the case involves descriptive claims about the environments of IPIs as well as the causal processes shaping policy-makers' representational design choices. As our goal is to explore the relevance of our conceptual distinction, we focus on the descriptive side of the debate by first discussing and then examining empirically the national and international context in which citizen-centred IPIs are likely to be found. Even though our goals are mainly descriptive, this discussion nevertheless requires awareness of the range of institutional decision-makers involved in creating and designing IPIs. Existing work has found that the proponents of IPIs differ from case to case. Mumford (2018:163) describes how experts used the design leeway that governments granted them to propose the creation of the ECOWAS IPI. In another recent study, Verdoes (2020) provides evidence of how members of national parliaments were the crucial actor behind the creation of the Benelux Parliamentary Assembly. In the well-known case of the European Parliament, design choices often followed advocacy by national and European parliamentarians (Rittberger 2005). It is important to note, however, that in all of these cases governments remained critical decisionmakers due to their formal authority over the design of IOs and IO bodies - other actors matter in many cases, but as a source of pressure on, rather than alternative to, governmental decision-makers.

The idea that IPIs could introduce citizen-centred representational designs in otherwise state-centred contexts has indeed played a role in academic and political discourse. For instance, campaigners for a UN parliament hope that even an initially weak and state-centred IPI would eventually evolve (Falk and Strauss 2001; Habegger 2010: 197-199). In this vein, state-centred parliaments could gradually become more citizencentred. Yet, in empirical terms, IPIs almost never change design. ${ }^{7}$ However, they might introduce new representational designs in world regions that otherwise exclude citizens from national and international

\footnotetext{
${ }^{7}$ There are only six design changes in our data. Three involve the (partial) introduction of direct elections. Moreover, MERCOSUR Parliament and the Nordic Assembly shifted to ideological factions. The MERCOSUR Parliament also moved to proportional seat allocation.
} 
political authority. For example, the 1979 Caracas Declaration in which parliamentary delegations from Bolivia, Colombia, Ecuador, and Venezuela—most of which were undemocratic regimes at the time—first proposed the Andean Parliament, reflects this idea (Pico Mantilla 1981:89):

...there is a struggle to keep the values of representative democracy, to give to the people legitimate participation in making their own destiny. Hence, the parliament is the genuine representation of the popular sovereignty and the conscious vigilance of the acts of our governors. Without its existence our countries would not conceive the validity of democracy. This philosophy inspires us to propose the creation of the Andean Parliament...

Yet, counter-arguments suggest that citizen-centred representational designs are more likely in IOs and countries that are already committed to, or are at least compatible in terms of goals and structures with, citizen representation in domestic politics and at the international level. Existing studies suggest that a range of institutional outcomes that encourage representation other than by governments are most common if democratic norms at the domestic level are strong. For example, IOs with democratic member states are also most likely to allow for the representation of civil society and to have IPIs in the first place (Tallberg et al. 2016; Rocabert et al. 2019). Democratic governments might be ideologically in favour of, institutionally familiar with, or politically under pressure from citizens to support citizen-centred representation in IOs. It seems likely, therefore, that citizen-centred representational designs in IPIs would be most likely in IOs run exclusively or predominantly by democratic governments.

Other arguments indicate that citizen-centred representational designs might mainly exist in IOs that pursue regional integration projects. In contrast, these representational designs might be less compatible with or useful for other IOs. Regional integration projects are commonly assumed to require a sense of regional identity and community and, therefore, institutions that promote these outcomes (Börzel \& Risse, 2019; Checkel, 2016). Regional integration projects have a plausible use for institutions that could broaden representation beyond governments and enable the formation of cross-border alignments such as party 
groups. The creation of citizen-centred IPIs is one of the main institutional strategies that governments could pursue so as to help their IOs promote regional integration.

IOs that pursue regional integration are likely to create citizen-centred IPIs for a second reason. They often have enhanced legitimation needs because their legislative agendas tend to be less predictable. This renders the creation of additional legitimation mechanisms, including citizen-centred parliaments that broaden representation beyond intergovernmental organs, potentially attractive for governments. This argument builds on Lenz et al. (2015) who suggest that regional integration projects can be characterized as so-called general-purpose organisations. This means that they are not only defined by region-building ambitions, such as the EU's effort to create an 'ever closer union among the peoples of Europe'. ${ }^{8}$ They also have open-ended goals to enact region-building. Of course, as all IOs, general-purpose IOs list their goals in treaties, and some start with a short list such as the European Coal and Steel Community. It is also true that generalpurpose IOs often have stronger competences in the area of economic integration than in other domains. However, even then general-purpose is visible in the goal to grow into a regional organization, develop an open-ended legislative agenda, and rely on generical procedures such as the EU's 'ordinary legislative procedure' that applies whenever the treaties do not explicitly provide for another procedure. While citizencentred IPIs are not the only enhanced legitimation strategy for general-purpose IOs, they are one prominent strategy that governments might pursue.

Another line of reasoning focuses on the IO membership. Many state-centred regions and IOs are at the same time heterogeneous in terms of socio-economic conditions. For example, many African regional organizations bring together rather different countries. Yet, the creation of more citizen-centred bodies at the international level is often said to be easier in homogenous environments (e.g., Koenig-Archibugi 2011). Even in the comparatively wealthy and homogeneous European Union, diversity is often considered an obstacle for the common elections, shared public debate, and transnational alliances that form the core of citizen-centred parliaments (e.g., Cheneval and Schimmelfennig 2013; Hale and Koenig-Archibugi 2016).

\footnotetext{
${ }^{8}$ See the Preamble and Article 1 of the Treaty on European Union, available at (accessed 4 May 2019): https://eurlex.europa.eu/collection/eu-law/treaties/treaties-force.html.
} 
In light of this, IPIs might be found in socio-economically homogenous environment rather than in statecentred regions and organizations that often are more heterogeneous.

Finally, it has been suggested that IOs in general and IPIs in particular learn from the institutional design of other prominent organizations - most importantly, the European Union (Börzel and Risse 2012; Lenz and Burilkov 2017). The European Union is the most authoritative IO and the European Parliament the most authoritative and most visible IPI in the world (Hooghe et al. 2017; Cofelice \& Stavridis 2014). This has not always been the case, however. The European Parliament started as a weak assembly and relatively marginal part of the early European integration organizations. It has always had citizen-centred traits cross-border factions, proportionally allocated seats and, since 1979 direct elections - but only began to gain significant legislative authority with the 1986 Single European Act (Rittberger 2005). It is likely that the growing authority of the EP has, over time, increased its visibility and status. This might have motivated IOs elsewhere to examine and potentially import not only its legislative authority but also its citizen-centred representational design. Moreover, Navarro (2010: 206-208) suggests that the European Parliament might use its authority to demand greater influence on the EU's policy towards other regional integration projects and might thus promote the export of its own representational design to interlocutors such as the Pan-African Parliament. On the other hand, some doubt is warranted based on the fact that the EP's authority has increased the most during a time period, since 1986, when predominantly state-centred IPIs emerged. The Pan-African Parliament on which Navarro focuses has remained state-centred except for the intention to hold direct elections in the future. Some Latin American parliamentary bodies also committed to direct elections in this period (Jancic 2019).

\section{Correlates of citizen-centred IPIs}

\section{Variables and data}

We start from our sample of 38 IPIs. For each, we identified a limited number of moments in which we take stock of their environment. We focussed on the foundation of IPIs, when they reformed their fundamental documents (such as when they reform internal rules), and on periods in which the IOs to which they belong 
changed their treaties. This yields 116 observations. This approach serves two purposes. First, it avoids focussing only on the contemporary or foundational context of IPIs, which might have changed. Second, we zoom in on moments in which the representational design of IPIs might have been under scrutiny and their environment especially relevant. Of course, we could have considered all years of the existence of an IPI. Not doing so means that we miss changes in their environment outside of their foundation and IO treaty reform. Yet, restructuring our data to encompass all years does lead to very similar results (see appendix).

We measure four variables corresponding to the arguments made in the previous section. First, the level of democracy of the member countries of an IO is measured as their mean score on the Polity V index (Marshall et al. 2020). Below and in the appendix, we also consider alternative operationalizations: the share of democratic countries instead of the mean as well as mean democracy measured with the Varieties of Democracy (V-Dem) 'Polyarchy index' (Coppedge et al. 2020).

Second, we argued that IOs engaged in region-building might differ from other IOs because of their distinct goals and general-purpose character. As no systematic data is available for this distinction, we manually coded the treaties and subsequent reforms of all IOs to which the IPIs in our data belong. Following Lenz et al. (2015), we identified IOs with treaties that state region-building ambitions or contain an open-ended list of goals and objectives. These may also be contained in the preamble-e.g. as the European Union's mandate to build an 'ever closer union—while the treaty allows the members to set new objectives in the future. We refer to these organizations as regional integration projects and general-purpose organizations interchangeably.

Third, measuring the homogeneity of IO member states on a global scale requires simplification and indicators that are comparable and available across regions. Our assumption is that a country's level of economic development to some extent captures the types of problems and conflicts that it faces and the political organizations it gives rise to. We operationalize economic homogeneity as diversity in economic development as measured by the standard deviation (SD) of the GDP per capita of IO members. We additionally examine the SD of IO member state populations. Similar populations might, in particular, 
facilitate agreement on proportional seat allocation in IPIs. Homogeneity could, of course, be measured differently. We consider alternatives in the appendix.

Finally, to test the idea that the development of the European Parliament holds a relationship with the designs of other IPIs we created a measure of decision-making authority for IPIs on the basis of their prerogatives on IO decision-making, which we coded on a 0 to 5 scale from no rights to sole decisionmaking over IO legislation. ${ }^{9}$ We use the EP values of this measure in the analysis below. In the EP case, the cooperation instituted in the Single European Act of 1987 and the co-decision of the Maastricht Treaty in 1992 were the two major advancements of its authority. They respectively mandated the IO to respond to the consultations of its IPI and to obtain its consent. This gave the EP veto right in most policy areas, which only one other IPI has, the East African Legislative Assembly.

\section{Bivariate relationships}

In Figure 2, we examine how the variables discussed in the previous section relate to citizen-centred representational designs. As explained, the cases in the figure correspond to observations of IPIs at their foundation and in years with treaty reforms of the IOs to which they belong. Panel a) shows that almost all wholly or partly citizen-centred IPIs can be found in democratic IOs. Democracy, in fact, comes close to a necessary condition in the absence of which IO member states almost invariably create state-centred parliamentary bodies. In contrast, however, democracy is not a sufficient condition for citizen-centred representation. There are several democratic IOs without citizen-centred IPIs. Alternative democracy measures result in similar impressions (see Figure A1 in the Appendix).

\footnotetext{
${ }^{9}$ The scale of the decision-making authority index is: (0) no formal rights, (1) information about IO agenda, (2) obligatory consultation, (3) right to a response to consultation, (4) veto rights, (5) exclusive IPI decision. In the appendix we provide further detail on this indicator.
} 
Figure 2. Explanatory variables and citizen-centred representational designs in the analysis sample

a) Average member state democracy

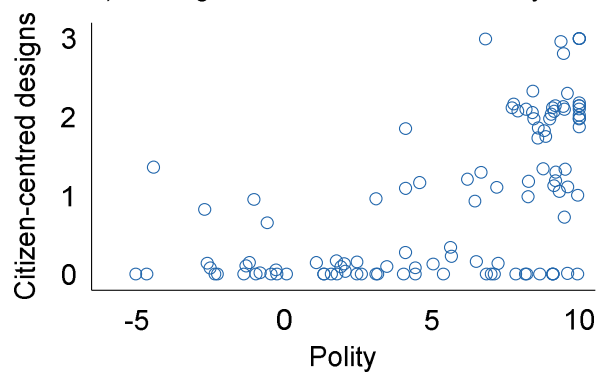

c) Standard deviation of population

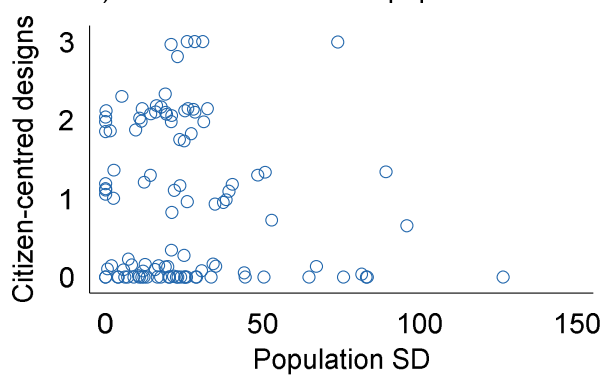

b) General-purpose and task-specific IOs

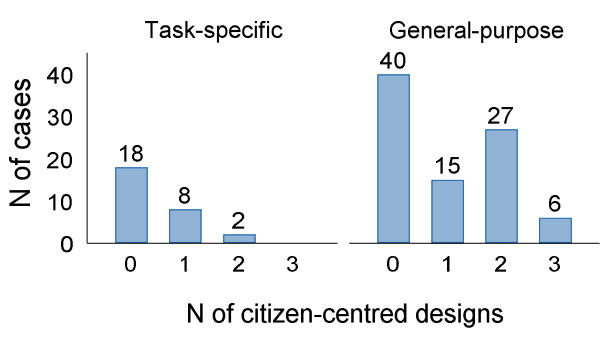

d) Standard deviation of GDP per capita

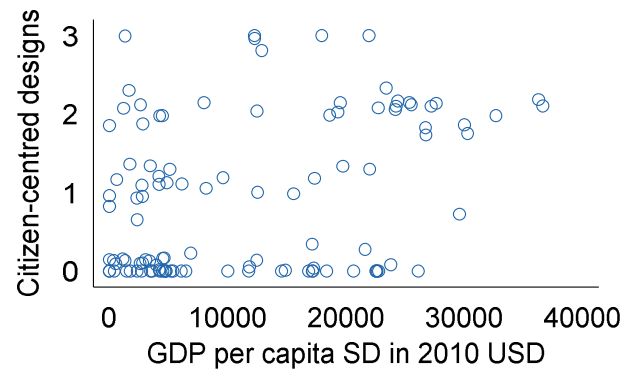

Panel b) of Figure 2 focuses on the purpose of IOs. Like democratic IOs, the general-purpose organizations typically associated with regional integration appear prone to establishing citizen-centred parliaments. Most such IPIs, including all wholly citizen-centred ones and all with direct elections, can be found in generalpurpose IOs. However, as member state democracy, general organizational purpose is not sufficient. There are exceptional positive cases. The assemblies of BENELUX and the OSCE are (partly) citizen-centred IPIs in task-specific IOs. There also are fairly many cases of general-purpose IOs with state-centred parliaments.

Panels c) and d) focus on homogeneity in the populations and economic development of IO member states. Here, the associations are less clear, but citizen-centred IPIs do seem more common in homogenous IOs. Nevertheless, there are outliers including, in Panel c), the case of the Russia-Belarus Union State, which allocates seats proportionately despite the fact that Russia is 15 times larger than Belarus. However, our 
preference to err on the side of citizen-centred designs overstates this discrepancy as Russia only receives 2.6 times more seats.

The legislative authority of the European Parliament in the EU is negatively correlated with the number of citizen-centred designs in our analysis sample $(\mathrm{r}-0.28)$. This is largely due to the fact that in most of our observations (those starting in the 1990s and later) when the legislative powers of the EP were already high, most IPI still have 0 or only 1 citizen-centred design.

Overall, citizen-centred representational designs are mainly a feature of the most democratic regional integration projects. They also seem to be more common in economically homogenous organizations, making the comparatively democratic, wealthy and ambitious European integration project the paradigmatic example of an organization with a citizen-centred parliament. Elsewhere in the world, where international as well as domestic affairs are more state-centred and fragmented, parliamentary bodies are more statecentred as well. Considered in conjunction with our earlier description of the historical development and distribution of the characteristics of IPIs, we thus see that citizen-centred representational designs have not only remained relatively rare overall, but have also rarely spread to the state-centred national and international contexts in which they might have proved most relevant.

\section{Multivariate relationships}

We examine these patterns further on the basis of a logistic regression analysis in which the outcome is whether an IPI is citizen-centred or not. We understand this to mean that it has at least two citizen-centred characteristics. In a second step, we examine each design feature separately. The structure of our data remains as discussed. Our goal is to deepen the systematic description of the contexts in which IPIs exist.

Table 3 shows the results of the first analysis. The results are generally in line with the impressions obtained so far. There is a positive and significant association between the average level of democracy of IO member states and the existence of citizen-centred IPIs. Beyond this, the evidence is more uncertain, however. The coefficient of IO purpose points in the direction seen in the bivariate analysis, albeit with a high $p$ value. Whether IOs are homogenous or heterogeneous in wealth and population does not seem to relate to citizen- 
centred designs with any degree of strength or certainty. The model also contains the index of the EP decision-making authority as a covariate. The inconclusive results, in conjunction with the fact that citizencentred designs have remained the exception, does not warrant confidence in the idea that the EP's legislative authority shapes representational design around the world.

Figure 3 visualizes the strength of two of these relationships, for member state democracy and IO purpose. We estimate that the probability to observe a citizen-centred IPI is about 60 percent in the most democratic and nearly absent in the least democratic IOs. General-purpose IOs are more likely to have citizen-centred IPIs although, in line with the fact that this relationship is not significant, the confidence intervals are wide.

Table 3. Correlates of citizen-centred designs

\begin{tabular}{llll}
\hline & $\boldsymbol{\beta}$ & SE & $\mathbf{p}$ \\
\hline Democracy mean & 0.55 & 0.14 & 0.00 \\
General-purpose IO & 2.06 & 1.60 & 0.10 \\
Population SD & -0.00 & 0.01 & 0.81 \\
GDP per capita SD & 0.00 & 0.00 & 0.14 \\
EP authority & -0.33 & 0.61 & 0.58 \\
Constant & -6.86 & 2.91 & 0.01 \\
Observations & $111(35$ IPIs) \\
\hline
\end{tabular}

Note: Standard errors are clustered by IPI. SE: Standard error. 


\section{Figure 3. Predicted probabilities}

a) Member state democracy

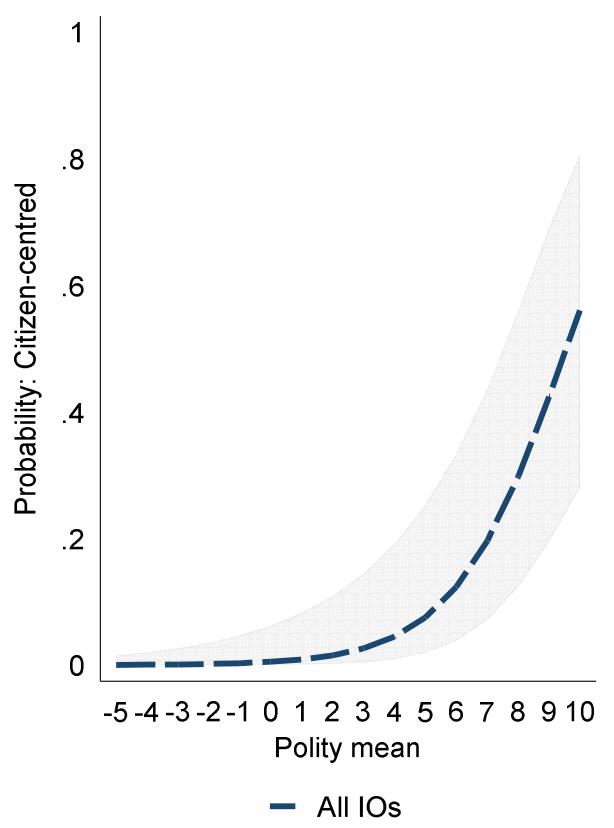

b) IO Purpose

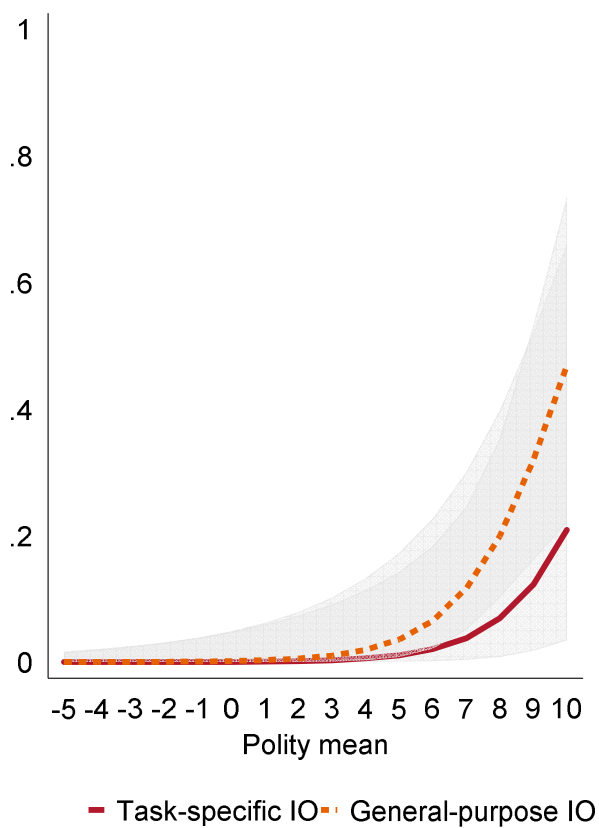

Table 4 summarizes the results of an analysis with the presence or absence of each citizen-centred design as the outcome. While one could have imagined differences in the typical contexts of different designs, the findings are similar to the previous analysis. There is a positive relationship between the level of democracy of IO members and direct elections or the non-territorial organization of the IPI, but proportional seat allocation seems to be a characteristic that also non-democratic IPIs have. Second, the associations between citizen-centred designs and general-purpose IOs are also different between designs. While belonging to a general-purpose IOs seems to matter for citizen-centred parliamentary factions, it does not matter for seat allocation, a design that IPIs adopt more easily. Our categorization of the purpose of IOs is not included in the first model because there are no task-specific IOs that hold elections. We also observe similar, albeit mostly insignificant, relationships between homogeneity in economic development and different citizencentred design dimensions. One additional insight of the disaggregated analysis pertains to population size. Although the most heterogeneous IOs today have IPIs with seats in proportion to population, considering 
all cases in our analysis sample this is not necessarily the case. For instance, out of the five time points at which we observe the IPI of Mercosur, three of those correspond to the time at which the IPI still had an equal number of seats per country. Consequently, the coefficient in the regression is close to 0 .

Table 4. Disaggregating citizen-centred designs

\begin{tabular}{l|llllll|llll}
\hline & \multicolumn{3}{l}{ Elections } & \multicolumn{4}{l}{ Seat allocation } & \multicolumn{3}{l}{ Factions } \\
& \multicolumn{1}{l}{} & $\mathbf{S E}$ & $\mathbf{p}$ & $\boldsymbol{\beta}$ & $\mathbf{S E}$ & $\mathbf{p}$ & $\boldsymbol{\beta}$ & $\mathbf{S E}$ & $\mathbf{p}$ \\
\hline Democracy mean & 0.64 & 0.17 & 0.00 & 0.18 & 0.11 & 0.10 & 0.59 & 0.13 & 0.00 \\
General-purpose IO & & & & 0.15 & 0.91 & 0.86 & 2.28 & 1.66 & 0.08 \\
Population SD & -0.16 & 0.01 & 0.31 & 0.00 & 0.01 & 0.53 & 0.00 & 0.01 & 0.73 \\
GDP per capita SD & -0.00 & 0.00 & 0.02 & 0.00 & 0.00 & 0.03 & 0.00 & 0.00 & 0.19 \\
EP authority & 1.30 & 0.44 & 0.00 & -1.17 & 0.44 & 0.00 & -0.26 & 0.61 & 0.66 \\
Constant & -9.29 & 1.78 & 0.00 & 1.59 & 1.51 & 0.29 & -7.72 & 3.05 & 0.01 \\
Observations & $111(35$ IPIs) & & 107 (34 IPIs) & & $111(35$ IPIs) & \\
\hline
\end{tabular}

Note: Standard errors are clustered by IPI. The first model excludes the general-purpose variable because all elected IPIs are found in general-purpose IOs. SE: Standard error. The model on seat allocation has less observations, corresponding to the IPI of the Union for the Mediterranean, which has an allocation system that is not captured by our category.

Citizen-centred designs might have become more widespread as the European Parliament has gained prominence. However, as in the previous analysis, we find no or reverse relationships between citizencentred design and EP authority. However, we find an association between the legislative authority of the EP and direct elections in other IPIs. Given that this relationship is limited to direct elections, caution is warranted before interpreting this association as potentially causal. For example, direct elections could be the result of global expectations or norms for the design of parliamentary bodies that have evolved in parallel to the growing legislative authority of the EP. Yet, as our goal is not to test causal claims, it holds true descriptively that direct elections, but not other citizen-centred traits, appear to have become more common as the most prominent citizen-centred IPI, the European Parliament, has gained authority.

In sum, the multivariate analysis reinforces the impression from the previous sections that citizen-centred international parliaments are primarily a feature of the world's most democratic, general-purpose IOs. While these patterns might be causal or starting points for causal claims, our goal here has been to examine whether 
citizen-centred representational designs are likely to be found in otherwise state-centred context where their potential to foster representation of alternative actors, concerns, and cross-border alignments than intergovernmental organs might matter most. However, our results warrant scepticism. The IPIs that exist in such environments have state-centred characteristics almost invariably.

\section{Conclusion}

In contemporary IOs, IPIs are not only increasingly common but also often regarded as mechanisms for democratic representation (Falk and Strauss 2001; Kissling 2014; Lenz 2013; Kraft-Kasack 2008; Šabič 2008; Rocabert et al. 2019). Yet, their representational design varies. This variation is likely to foster the representation of different actors and concerns. This study has developed this idea further by delineating important representational design alternatives - state-centred and citizen-centred representational designs and mapping their existence and correlates in IOs around the world. Drawing on new data, we found that citizen-centred IPIs have remained a rare and a near-exclusive phenomenon of a few democratic and advanced regional integration projects. Democracy among IO member states and the general organizational purpose associated with regional integration appear to be especially typical contexts for direct elections and cross-border IPI factions, as for example the transnational ideological groups of the European Parliament. These conditions are less regularly associated with allocation of IPI seats in proportion to population, however.

These results do not imply that IPIs fail to add to the channels of representation existing in IOs. Irrespective of their representational design, IPIs bring together directly or indirectly elected political actors and thus different actors than the agents of national governments found in intergovernmental IO bodies. However, our findings suggest that the actors and concerns represented in IPIs might prove more similar to intergovernmental bodies than they could be if citizen-centred representational designs were more widespread. Existing literature indicates that different design choices could enhance the likelihood that IPIs give expression to cross-border political communities, concerns and conflict lines that differ from those represented in intergovernmental IO bodies (Jancic 2019: 229; Habegger 2010; Cofelice 2019:188-189; Dri 
2010: 65-70). The literature on the European Parliament similarly suggests that its cross-border factions, direct elections, and population-oriented seat allocation foster legislative behaviour independent of, and frequently in conflict with, the Council of Ministers (Hix 2002; Rittberger 2005). Yet, these citizen-centred representational designs remain the exception in global comparison and are especially rare in otherwise state-centred domestic contexts and IOs. Most IPIs are thus unlikely to challenge intergovernmental IO bodies in the same sustained way as the EP has frequently done not only because they often lack institutional authority, but also because of their predominantly state-centred representational designs.

Further research could build on these results. As noted earlier, the claim the representational design influences the actors and concerns represented in IPIs requires conceptualizing and mapping relevant design alternatives as well as testing their behavioural implications. In this study, we have focused on the first of these steps, which is a prerequisite for testing the consequences of variation in design on representationrelated behavioural outcomes such as the characteristics and ideological orientation of or representational claims made in speeches by IPI members. Similarly, future research could further test the causes and mechanisms leading to the creation of IPIs with different representational designs. We focused on describing the typical environments of state-centred and citizen-centred IPIs but more systematic analysis, including potentially case studies of causal mechanisms or qualitative comparative analysis of the configurations of causes leading to design choices, might allow causal claims.

We conclude with two broader observations. While state-centred IPIs remain the rule, advocates of citizencentred representational designs might hope that this might change over time. Yet, is it likely that more citizen-centred parliaments might emerge over time? If we take our results as indication of possible causal drivers of representational designs, they suggest that the future of citizen-centred IPIs depends on the success of democracy and the general-purpose IOs associated with regional integration projects. Against this background there is reason to be sceptical. First, there is little room for more citizen-centred designs in favourable contexts. Consider all IOs with IPIs in 2017. Of these only six (the Central American Integration System, Mercosur, the Organization of Eastern Caribbean States, Benelux, European Union, and the Andean Community) had a general-purpose and were democratic (with a Polity V average above 6)-yet, only the 
parliaments of the Caribbean States and Andean Community had fewer than two citizen-centred characteristics already. Second, if there is no growth potential given the existing IOs, the further spread of citizen-centred designs would require that more IO member states become democracies and more regional integration projects emerge. However, the opposite actually appears to be in process. Many observers identify a risk of a "democratic recession" (Diamond 2015; Bermeo 2016; but see Levitsky and Way 2015), not least in the European and Latin American heartlands of citizen-centred IPIs. Others highlight the politicization and contestation of regional integration and multilateral institutions, although here the picture is mixed and some argue that more rather than less citizen representation could be the result (Zürn 2014; Börzel and Risse 2016). Given these trends, the representational designs of international parliaments are likely to remain mainly state-centred for the foreseeable future.

Finally, we have focused on IPIs and concluded, albeit bearing in mind several open questions, that these bodies might not promise as different representation from intergovernmental IO bodies as superficial observation might indicate at first. What does this imply for policy-makers, activists, and scholars seeking to broaden representation in IOs and beyond? Our analysis suggests two arguments. On one hand, if the goal is to broaden representation, then there might seem to be greater potential in function-centred bodies and processes. IOs have expanded representation not only by creating IPIs but also by strengthening the representation of civil society organizations and, more broadly, stakeholders (e.g., Tallberg et al. 2013). Even beyond IOs, "multistakeholder" governance processes have become widespread (e.g., Raymond and de Nardis 2015). On the other, some caution is warranted. In a similar way that the concept of representational design has led us to a careful view as to the potential of IPIs to represent new actors and concerns in IOs, this concept could also contribute to a more systematic assessment of the nature of representation that multistakeholder governance in and beyond IOs could actually be expected to offer.

\section{References}

Agné, H., Dellmuth, L. M., \& Tallberg, J. (2015). Does stakeholder involvement foster democratic legitimacy in international organizations? An empirical assessment of a normative theory. The Review of International Organizations, 10(4), 465-488. doi:10.1007/s11558-014-9212-6 
Baltic Assembly. (2017, November 10). Statutes of the Baltic Assembly. Retrieved from http://www.baltasam.org/images/2017/Session_36/Statutes_2017.pdf

Benz, A. (2003). Compound representation in EU multi-level governance. In B. Kohler-Koch (Ed.), Linking EU and National Governance (pp. 82-110). Oxford, UK: Oxford University Press.

Bermeo, N. (2016). On democratic backsliding. Journal of Democracy,27(1), 5-19. doi:10.1353/jod.2016.0012

Blake, D. J., \& Payton, A. L. (2015). Balancing design objectives: Analyzing new data on voting rules in intergovernmental organizations. The Review of International Organizations, 10(3), 377-402. doi:10.1007/s11558-014-9201-9

Blanco, Patricia. (2019). La Cámara Electoral aceptó un pedido del Frente de Todos y le ordenó al Gobierno que convoque a elecciones para elegir diputados del Parlasur. InfoBae. Retrieved from https://www.infobae.com/politica/2019/10/22/la-camara-electoral-acepto-un-pedido-del-frente-detodos-y-le-ordeno-al-gobierno-que-convoque-a-elecciones-para-elegir-diputados-del-parlasur/

Börzel, T. A., \& Risse, T. (2012). When Europeanisation meets diffusion: Exploring new territory. West European Politics, 35(1), 192-207. doi:10.1080/01402382.2012.634543

Börzel, T. A., \& Risse, T. (2016). Introduction: Framework of the handbook and conceptual clarifications. In T. A. Börzel \& T. Risse (Eds.), The oxford handbook of comparative regionalism (pp. 3-15). Oxford, UK: Oxford University Press.

Börzel, T. A., \& Risse, T. (2019). Grand theories of integration and the challenges of comparative regionalism. Journal of European Public Policy, 26(8), 1231-1252. doi:10.1080/13501763.2019.1622589

Börzel, T. A., \& Risse, T. (2019). Identity politics, core state powers, and regional integration: Europe and beyond. JCMS: Journal of Common Market Studies, 58(1), 21-40. doi:10.1111/jcms.12982

Bowler, S., \& Farrell, D. M. (1995). The organizing of the European Parliament: Committees, specialization and co-ordination. British Journal of Political Science, 25(2), 219-243. doi:10.1017/S0007123400007158

Bustamante, A. (2015, August 24). Elección de diputados al Parlacen divide la CNRE. La Prensa/Panorama. Retrieved from https://impresa.prensa.com/panorama/Eleccion-diputadosParlacen-divide-CNRE_0_4285071538.html

Carey, J. M. (2007). Competing principals, political institutions, and party unity in legislative voting. American Journal of Political Science,51(1), 92-107. doi:10.1111/j.15405907.2007.00239.x

Carey, J. M., \& Shugart, M. S. (1995). Incentives to cultivate a personal vote: A rank ordering of electoral formulas. Electoral Studies, 14(4), 417-439. doi:10.1016/0261-3794(94)00035-2

Checkel, J. T. (2016). Regional identities and communities. In T. A. Börzel \& T. Risse (Eds.), The oxford handbook of comparative regionalism (pp. 559-578). Oxford, UK: Oxford University Press.

Cheneval, F. (2011). The government of the Peoples: On the idea and principles of multilateral democracy. New York, NY: Palgrave Macmillan.

Cheneval, F., \& Schimmelfennig, F. (2013). The case for demoicracy in the European Union. JCMS: Journal of Common Market Studies, 51(2), 334-350. doi:10.1111/j.1468-5965.2012.02262.x

Cofelice, A. (2018). Parliamentary institutions in regional and international governance: Functions and powers. New York, NY: Routledge.

Cofflice, A., \& Stavridis, S. (2014). European Parliament as an International Parliamentary Institution (IPI). European Foreign Affairs Review, 19, 145-178.

Community of Portuguese Language Countries. (2009). Regimento da Assambleia Parlamentar da CPLP.

Coppedge, M., Gerring, J., Knutsen, C. H., Lindberg, S. I., Teorell, J., Altman, D., ... \& Lührmann, A. (2020). "V-Dem [Country-Year/Country-Date] Dataset v10". Varieties of Democracy (V-Dem) Project. doi:10.23696/vdemds20

Cutler, R. M. (2001). The emergence of international parliamentary institutions: New networks of influence in world society. In G. S. Smith \& D. Wolfish (Eds.), Who is afraid of the state? Canada in a World of Multiple Centres of Power (pp. 201-229). Toronto, Canada: University of Toronto Press.

De Puig, L. M. (2008). International parliaments. Strasbourg, UK: Council of Europe. 
Diamond, L. (2015). Facing up to the democratic recession. Journal of Democracy, 26(1), 141-155. doi:10.1353/jod.2015.0009

Dingwerth, K., Schmidtke, H., \& Weise, T. (2019). The rise of democratic legitimation: why international organizations speak the language of democracy. European Journal of International Relations. doi: $10.1177 / 1354066119882488$

Döring, H. (Ed.). (1995). Parliaments and majority rule in Western Europe. New York, NY: St. Martin's Press.

Dri, C. F. (2010). Limits of the institutional mimesis of the European Union: The case of the Mercosur Parliament. Latin American Policy, 1(1), 52-74. doi:10.1111/j.2041-7373.2010.00004.x

Ecker-Ehrhardt, M. (2018). Self-legitimation in the face of politicization: Why international organizations centralized public communication. The Review of International Organizations, 13(4), 519-546. doi:10.1007/s11558-017-9287-y

El Nacional. (2015, December 21). TSJ Decide En Abril Sobre Elecciones Del Parlatino. Retrieved from https://www.elnacional.com/venezuela/politica/tsj-decide-abril-sobre-elecciones-delparlatino_38581/

Falk, R., \& Strauss, A. (2001). Toward global parliament. Foreign Affairs, 80, 212-217.

Fish, M. S., \& Kroenig, M. (2009). The handbook of national legislatures: A global survey. Cambridge, UK: Cambridge University Press.

Giesen, M. (2017). Regional parliamentary institutions: Diffusion of a global parliamentary organizational design? Social Science Open Access Repository (SSOAR). Retrieved from https://www.ssoar.info/ssoar/bitstream/handle/document/57748/ssoar-2017-giesen-

Regional_Parliamentary_Institutions_Diffusion_of.pdf?sequence $=1$ andisAllowed $=$ yandlnkname $=$ ssoar-2017-giesen-Regional_Parliamentary_Institutions_Diffusion_of.pdf

Grabendorff, W. (1992). The European parliament and the Central American parliament: The parliamentary dimension of relations between Central America and the European community. In J. Roy (Ed.), The reconstruction of Central America: The role of the European community (pp. 95-105). Miami, North-South Center, University of Miami.

Guerrieri, S. (2008). The start of European integration and the parliamentary dimension: The Common Assembly of the ECSC (1952-1958). Parliaments, Estates \& Representation, 28(1), 183-193. doi:10.1080/02606755.2008.9522283

Habegger, B. (2010). Democratic accountability of international organizations: Parliamentary control within the Council of Europe and the OSCE and the prospects for the United Nations. Cooperation and Conflict, 45(2), 186-204. doi:10.1177/0010836709347218

Hagemann, S., \& Høyland, B. (2010). Bicameral politics in the European Union. JCMS: Journal of Common Market Studies, 48(4), 811-833. doi:10.1111/j.1468-5965.2010.02075.x

Hale, T., \& Koenig-Archibugi, M. (2016). Are Europeans ready for a more democratic European Union? New evidence on preference heterogeneity, polarisation and crosscuttingness. European Journal of Political Research, 55(2), 225-245. doi:10.1111/1475-6765.12136

Hall, H. D. (1942). The Community of the Parliaments of the British Commonwealth. American Political Science Review, 36(6), 1128-1135. doi:10.2307/1949071

Héritier, A. (2007). Explaining Institutional Change in Europe. Oxford, UK: Oxford University Press.

Hix, S. (2002). Parliamentary behavior with two principals: Preferences, parties, and voting in the European Parliament. American Journal of Political Science, 46(3), 688-698. doi:10.2307/3088408

Hix, S., Noury, A. \& Roland, G. (2007). Democratic Politics in the European Parliament. Cambridge University Press CBO9780511491955.

Hooghe, L, Marks, G., \& Lenz, T. (2017). Community, scale and the design of international organization. A postfunctionalist theory of governance, volume 4. Oxford, UK: Oxford University Press.

Hovey J. (1966) The Superparliaments: Interparliamentary consultation and Atlantic cooperation. New York, NY: Frederick A. Praeger.

Hurd, I. (1999). Legitimacy and authority in international politics. International Organization, 53(2), 379408. doi:10.1162/002081899550913 
Jancic, D. (2019). Regional Parliaments and African Economic Integration. European Journal of International Law, 30(1), 199-228. doi:10.1093/ejil/chz006

Jönsson, C., \& Johnsson, A. (2018). Parliaments in Global Governance. Global Governance: A Review of Multilateralism and International Organizations, 24(3), 309-320. doi:10.1163/1942672002403001

Jönsson, C., Tallberg, J., Sommerer, T., \& Squatrito, T. (2013). The opening up of international organizations: Transnational access in global governance. Cambridge, UK: Cambridge University Press.

Kam, C. (2014). Party Discipline. In S. Martin, T. Saalfeld, \& k. Strøm (Eds.), The oxford handbook of legislative studies (pp. 1-21). Oxford, UK: Oxford University Press.

Kingah, S., \& Cofelice, A. (2012). EU's engagement with African (Sub) Regional parliaments of ECOWAS, $S A D C$, the EAC and the $A U$. United Nations University Institute on Comparative Regional Integration Studies Potterierei: Belgium.

Kissling, C. (2014). The legal and political status of international parliamentary institutions. In G. Finizio, L. Levi, \& N. Vallinoto (Eds.), The democratization of international institutions (pp. 25-53). New York, NY: Routledge.

Klebes, H. (1990). The development of international parliamentary institutions. Constitutional and Parliamentary Information ASGP.-Geneva. 1st Series, (159/1st). Geneva: Association of Secretaries General of Parliaments.

Klebes, H. (1990). The development of international parliamentary institutions. Constitutional and Parliamentary Information ASGP.-Geneva. 1st Series, (159/1st). Geneva: Association of Secretaries General of Parliaments.

Koenig-Archibugi, M. (2011). Is global democracy possible? European Journal of International Relations, 17(3), 519-542. doi:10.1177/1354066110366056

Koremenos, B., Lipson, C., \& Snidal, D. (2001). The rational design of international institutions. International Organization, 55(4), 761-799. doi:10.1162/002081801317193592

Kraft-Kasack, C. (2008). Transnational parliamentary assemblies: A remedy for the democratic deficit of international governance?. West European Politics,31(3), 534-557. doi:10.1080/01402380801939818

Krehbiel, K. (1991). Information and legislative organization. Ann Arbor, MI: University of Michigan Press.

Lenz, T. (2013). The Politics of Institutional Symbolism: Parliamentarization in Regional Economic Organizations. Paper presented in the Conference "(De-) Legitimation of Global Governance Organizations, ” Bremen: University of Bremen.

Lenz, T., \& Burilkov, A. (2017). Institutional pioneers in world politics: Regional institution building and the influence of the European Union. European journal of international relations, 23(3), 654-680. doi: $10.1177 / 1354066116674261$

Lenz, T., Bezuijen, J., Hooghe, L., \& Marks, G. W. (2014). Patterns of international authority: Task-specific vs. general-purpose organizations. Politische Vierteljahresschrift, 49(2014 S), 107-132.

Levitsky, S., \& Way, L. (2015). The myth of democratic recession. Journal of Democracy, 26(1), 45-58. doi:10.1353/jod.2015.0007

Lipps, J. (2020). Intertwined parliamentary arenas. Why parliamentarians attend International Parliamentary Institutions. European Journal of International Relations. In press.

Løchen, E. (1958). A comparative study of certain European parliamentary assemblies. In B. Landheer \& W. H. Carter (Eds.), Annuaire Européen/European Yearbook (pp. 150-173). Springer, Dordrecht.

Majone, G. (2001). Two logics of delegation: agency and fiduciary relations in EU governance. European Union Politics, 2(1), 103-122. doi:10.1177/1465116501002001005

Malamud, A., \& De Sousa, L. (2016). Regional parliaments in Europe and Latin America: between empowerment and irrelevance. In A. Ribeiro Hoffmann \& A. van der Vleuten (Eds.), Closing or Widening the Gap? (pp. 109-126). New York, NY: Routledge.

Malang, T. (2019). Why national parliamentarians join international organizations. The Review of International Organizations, 14(3), 407-430. doi:10.1007/s11558-018-9314-7 
Marshall, M. G. (2020). Polity V project: Political regime characteristics and transitions, 1800-2018: Dataset Users' Manual. Maryland: University of Maryland.

Martin, S., Saalfeld, T., \& Strøm, K. (Eds.). (2014). The Oxford handbook of legislative studies. Oxford, UK: Oxford University Press.

Mumford, D. (2018). The power of experts: why non-democracies create regional parliaments ( $\mathrm{PhD}$ thesis). University of Oxford, United Kingdom.

Navarro, J. (2010). The creation and transformation of regional parliamentary assemblies: Lessons from the Pan-African Parliament. The Journal of Legislative Studies, 16(2), 195-214. doi:10.1080/13572331003740107

Parlamento del Mercosur. (2019). REC.05 2019 - Elecciones Directas En El Parlamento Del Meracosur. Retrieved from https://www.parlamentomercosur.org/innovaportal/file/16585/1/rec.05-2019.pdf

Pico, M. G. (1981). Declaración de Caracas (1979). Quito, Ecuador: Cámara Nacional de Representates.

Powell, G. B., \& Powell Jr, G. B. (2000). Elections as instruments of democracy: Majoritarian and proportional visions. New Haven, CT: Yale University Press.

Rapkin, D. P., Strand, J. R., \& Trevathan, M. W. (2016). Representation and governance in international organizations. Politics and Governance, 4(3), 77-89. doi:10.17645/pag.v4i3.544

Raymond, M., \& de Nardis, L. (2015). Multistakeholderism: Anatomy of an Inchoate Global Institution. International Theory 7 (3), 572-616. https://doi.org/10.1017/S1752971915000081.

Rittberger, B. (2005). Building Europe's Parliament: Democratic representation beyond the nation state. Oxford, UK: Oxford University Press.

Rivas Molina, Federico. (2019). El Mercosur suspende la elección directa de los diputados de su Parlamento. El País. Retrieved from https://elpais.com/internacional/2019/04/16/america/1555374301_791741.html

Rocabert, J., Schimmelfennig, F., Crasnic, L., \& Winzen, T. (2019). The rise of international parliamentary institutions: Purpose and legitimation. The Review of International Organizations, 14(4), 607-631. doi:10.1007/s11558-018-9326-3

Roederer-Rynning, C., \& Schimmelfennig, F. (2012). Bringing Codecision to Agriculture: A Hard Case of Parliamentarization. Journal of European Public Policy 19(7), 951-68. doi.org/10.1080/13501763.2011.652902.

Šabič, Z. (2008). Building democratic and responsible global governance: the role of international parliamentary institutions. Parliamentary Affairs, 61(2), 255-271. doi:10.1093/pa/gsm062

Schimmelfennig, F., Winzen, T., Lenz, T., Rocabert, J., Crasnic, L., Gherasimov, C., Lipps, J. \& Mumford, D. (2018). The rise of international parliaments: Strategic legitimation in international organizations. Oxford, UK: Oxford University Press (in press).

Scully, R. (2005). Becoming Europeans? Attitudes, behaviour and socialization in the european parliament. Oxford, UK: Oxford University Press.

Stavridis, S., \& Jancic, D. (Eds.). (2017). Parliamentary diplomacy in European and global governance. Boston, MA: Brill/Nijhoff.

Stravidis, S., \& Pace, R. (2011). Assessing the impact of the empas parliamentray diplomacy in international conflict: contribution or obstacle? In G. G. Clariana (Ed.), The Euro-Mediterranean assembly (pp. 59-105). Barcelona: Marcial Pons.

Strøm, K. (1998). Parliamentary committees in European democracies. The Journal of Legislative Studies, 4(1), 21-59. doi:10.1080/13572339808420538

Taagepera, R., \& Hosli, M. O. (2006). National representation in international organizations: the seat allocation model implicit in the European Union Council and Parliament. Political Studies, 54(2), 370-398. doi:10.1111/j.1467-9248.2006.00607.x

Tallberg, J., Sommerer, T., \& Squatrito, T. (2016). Democratic memberships in international organizations: Sources of institutional design. The Review of International Organizations, 11(1), 59-87. doi:10.1007/s11558-015-9227-7

Tallberg, J., Sommerer, T., Squatrito, T., \& Jönsson, C. (2014). Explaining the transnational design of $\begin{array}{lll}\text { international } & \text { organizations. International }\end{array}$ doi:10.1017/S0020818314000149 
Tallberg, J., \& Zürn, M. (2019). The legitimacy and legitimation of international organizations: introduction and framework. The Review of International Organizations, 14(4), 581-606. https://doi.org/10.1007/s11558-018-9330-7

Tsebelis, G., \& Rasch, B. E. (1995). Patterns of bicameralism. In H. Döring (Ed.), Parliaments and majority rule in western Europe (365-390). Frankfurt: Campus.

van der Schyff, G., \& Leenknegt, G. J. (2007). The Case for a European Senate. A model for the representation of national parliaments in the European Union. Zeitschrift für öffentliches Recht, 62(2), 237-258. doi:10.1007/s00708-007-0177-2

Vaubel, R. (2006). Principal-agent problems in international organizations. The Review of International Organizations, 1(2), 125-138. doi:10.1007/s11558-006-8340-z

Verdoes, A. (2020). Explaining the Emergence of International Parliamentary Institutions: The Case of the Benelux Interparliamentary Consultative Council. Parliamentary Affairs, 73(2), 385-407. doi:10.1093/pa/gsy054

Zürn, M. (2014). The politicization of world politics and its effects: Eight propositions. European Political Science Review, 6(1), 47-71. doi:10.1017/S1755773912000276 